\title{
Ordovician limestone clasts in the Lower Old Red Sandstone, Pentland Hills, southern Midland Valley Terrane
}

\author{
H. A. Armstrong1, A. W. OWen ${ }^{2}$ and E. N. K. Clarkson ${ }^{3}$ \\ ${ }^{1}$ Department of Geological Sciences, University of Durham, South Road, Durham DH1 3LE \\ ${ }^{2}$ Division of Earth Sciences, University of Glasgow, Gregory Building, Lilybank Gardens, \\ Glasgow G12 8QQ \\ ${ }^{3}$ Department of Geology and Geophysics, Grant Institute, University of Edinburgh, West Mains Road, \\ Edinburgh, EH9 3JW
}

\begin{abstract}
Synopsis
In the southern part of the Scottish Midland Valley Lower Old Red Sandstone sedimentary and volcanic strata of the Lanark Group unconformably overlie inliers of largely marine Silurian rocks. The oldest of the four formations of the Lanark Group is the Greywacke Conglomerate Formation which contains clasts predominantly of greywacke, with subordinate volcanic rocks, cherts and limestones. The greywackes are known to have been derived from a cryptic source which lay to the south and east of the Midland Valley. Contrary to earlier, Silurian, age assessments of limestone clasts from the Greywacke Conglomerate Formation of the Pentland Hills, a conodont faunule described herein belongs in the uppermost Llanvirn to lower Caradoc $P$. anserinus Biozone. There are no Ordovician rocks exposed within the Pentland Hills inlier, and thus our new age data suggest that along with the other clasts, the limestones in the Greywacke Conglomerate are exotic to the Pentlands Sub-basin. The source area had a cover succession that included mid-Ordovician shallow marine carbonate and fiysch.
\end{abstract}

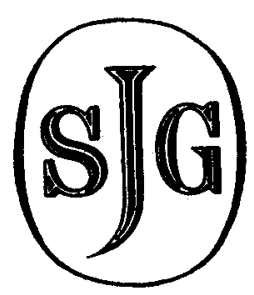

\section{Introduction}

In the southern part of the Midland Valley of Scotland a chain of inliers of variably deformed LlandoveryWenlock rocks is overlain unconformably by a thick Old Red Sandstone succession known as the Lanark Group. The latter was deposited in the Lanark Basin, which extended over much of the southern Midland Valley. Old Red Sandstone sedimentation may have begun as early as the Pridoli and continued through the early Devonian; the source being to the E and SE (Phillips et al. 1998). Of the four formations defined within the Lanark Group, the lowest is the Greywacke Conglomerate Formation. This contains mainly greywacke clasts with subordinate and variable amounts of volcanic rocks, quartzite, red chert and limestone clasts, and is compositionally very distinct from the older, Silurian conglomerate horizons. According to Mykura (1960) the Greywacke Conglomerate Formation in the Pentland Hills thins to the NE. Above it lie three formations of sedimentary and volcanic rocks including lavas dated at $412.6 \pm 5.7 \mathrm{Ma}$ (Thirlwall 1988). These suggest that the Greywacke Conglomerate may be earliest Devonian in age, the base of the Devonian system now being dated at about $418 \mathrm{Ma}$ (Tucker et al. 1998). The Greywacke Conglomerate Formation is seen to rest unconformably upon vertical Llandovery-Wenlock marine to terrestrial strata in three inliers in the Pentland Hills (Fig. 1; Pentlands Sub-basin sensu Phillips et al. 1998).
The Greywacke Conglomerate Formation is also present at the base of the Old Red Sandstone succession in other inliers in the southern part of the Midland Valley (McGiven 1967; Syba 1989). In the Hagshaw Hills, vertical stacking and predominance of proximal alluvial fan facies indicate that basin subsidence kept pace with or exceeded hinterland uplift during deposition (Syba 1989).

The greywacke clasts in the Greywacke Conglomerate in the Midland Valley were originally thought to resemble Silurian lithologies from the Southern Uplands (Bluck $1978,1983,1984)$. However, Syba (1989) demonstrated, on the basis of detailed petrographic studies, that the clasts are compositionally distinct from any greywackes in the Southern Uplands and suggested that they were derived from a flysch cover succession that extended across the Midland Valley Terrane. Phillips et al. (1998, p. 222) argued that the greywackes may have been sourced from a putative, possibly Llandovery, greywacke sandstone basin to the east.

The Bavelaw Inlier is one of three Silurian Inliers in the Pentland Hills and is the closest of the three to Edinburgh. Here in Logan Burn [NT 183 619], at Habbie's Howe, the Greywacke Conglomerate, locally known as the Loganlee conglomerate, directly overlies the Silurian and forms a prominent cliff with a waterfall. Limestone blocks from the exposed strata were discovered by Henderson (1874) who noted that they are less rounded than the other pebbles and thus probably of local origin. He further suggested (Henderson 1880) that they were derived from 


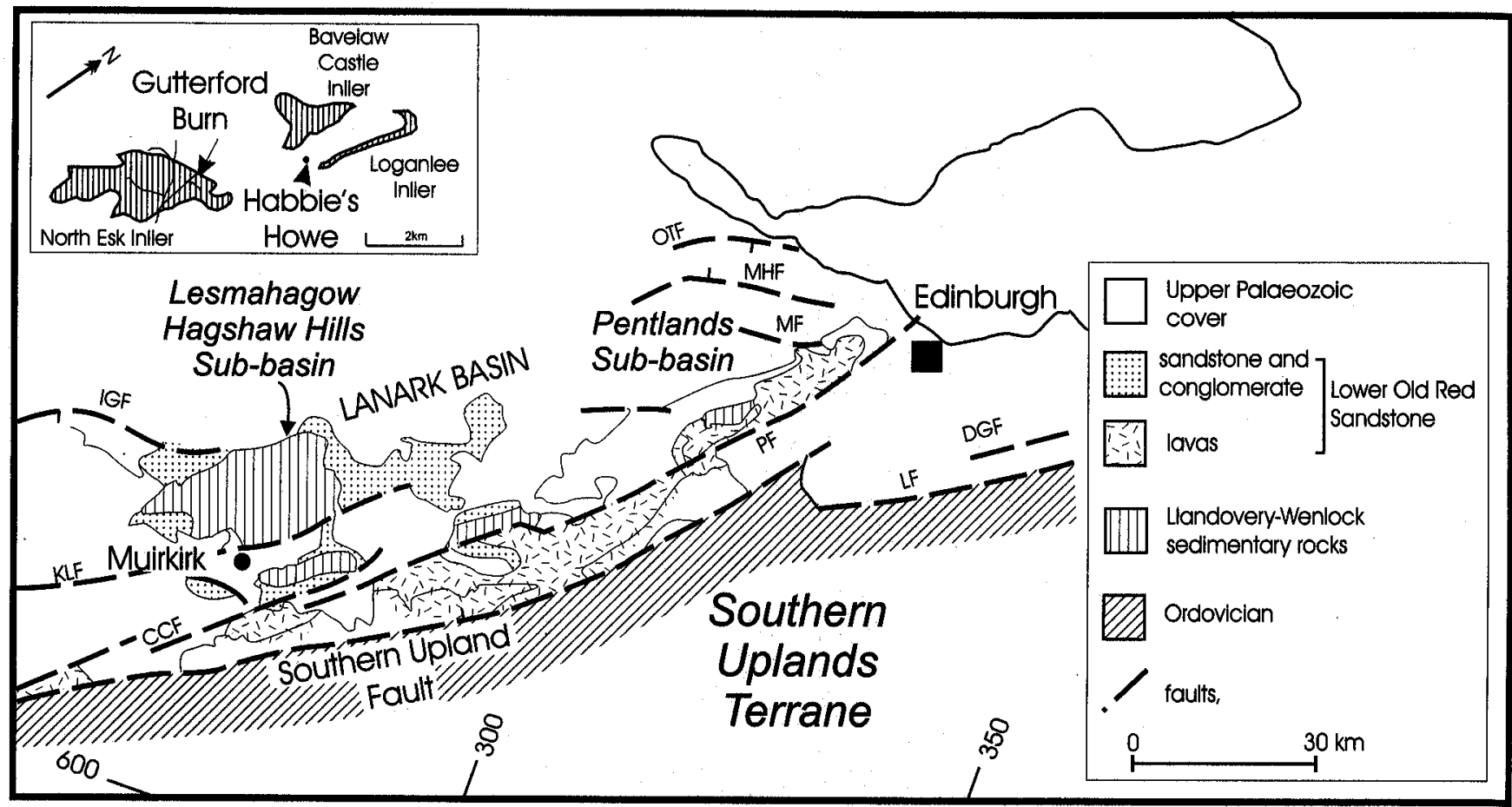

FIG. 1. General geological map of the southeastern Midland Valley of Scotland showing the distribution of the Ordovician, Silurian and Lower Old Red Sandstone sedimentary successions. Inset map shows the distribution of the three Silurian inliers in the Pentlands Sub-basin and localities mentioned in the text. The geology of the Southern Uplands has been omitted for clarity. Lower Old Red Sandstone lavas, the Lanark Basin and its principal sub-basins are marked (redrawn after Phillips et al. 1998). CCF Carmacoup Fault, DGF Dunbar-Gifford Fault, IGF Inchgotrick Fault, KLF Kerse Loch Fault, LF Lammermuir Fault, MF Murieston Fault, MHF Middleton Fault, OTF Ochiltree Fault, PF Pentland Fault.

bands of limestone similar to those cropping out in the Gutterford Burn $3 \mathrm{~km}$ to the SW [NT 160 595]. Peach and Horne $(1899$, p. 606) recorded a diverse fauna from limestone clasts at Habbie's Howe which included the corals Tetradium, Favosites, Halysites, Plasmopora, Heliolites and other fossils including trilobites, brachiopods and orthocones (see also Peach et al. 1910; Mitchell and Mykura 1962; Mykura 1986). Based on this fauna, Peach and Horne supported Henderson's contention that the clasts were from the Gutterford Burn Limestone.

Graptolites from the Gutterford Burn Limestone indicate an Upper Llandovery, crenulata graptolite Biozone age (Robertson 1989, Bull and Loydell 1995). Conodonts recently extracted (Armstrong and Scrutton unpublished data) indicate the limestone succession spans the Pterospathodus celloni - P. amorphognathoides conodont biozones, of latest Llandovery age.

If the limestone clasts at Habbie's Howe were derived from the Gutterford Burn Limestone, this would suggest the clasts within the Greywacke Conglomerate were derived both from local and extra-basinal sources. However, our reinvestigation of the fauna of the limestone clasts indicates a mid-Ordovician age, significantly older than previously thought.

\section{Clast lithologies and fauna}

Fossiliferous clasts exhibit a range of lithologies; typically they are bioclastic calcareous mudstones, bioclastic crystalline limestone or rare oolitic grainstones (British
Geological Survey, Edinburgh collections). Such a range of lithologies is consistent with a source within a shallow marine carbonate platform (M. E. Tucker, pers. comm. 1998).

The list of shelly fossils from limestone clasts in the Loganlee conglomerate given by Peach and Horne (1899, p. 606) gives a good picture of the spectrum of organisms present. The collections of the British Geological Survey in Edinburgh contain a rich and diverse assemblage of algae, solitary and tabulate corals, cephalopods, gastropods, echinoderms, brachiopods and trilobites from these clasts. Their detailed study is beyond the scope of the present work but it is clear that the specific and even generic identifications given by Peach and Horne are in need of modern interpretation. Two taxa have some historical significance and are worth some brief comment here.

Nicholson and Etheridge (1877) described one of the colonial organisms as a new coral species, Tetradium peachii and subsequently $(1878, \mathrm{pp} .31-33)$ ascribed other material to this species from the Craighead Limestone (middle Caradoc) of the Girvan district. In a later paper (1885), however, they placed the species in the synonymy of the lower Caradoc calcareous alga Solenopora compacta Billings. Their important conclusion that the Loganlee clasts are Ordovician in age has hitherto been ignored.

Lamont (1948) established the monotypic harpid trilobite genus Metaharpes on the basis of a lower lamella of a fringe from the Loganlee conglomerate. He named Metaharpes amibouei in honour of the geologist Ferdinand 
Amiboué, a refugee from the French Revolution. The sole descriptive comment was that the pits become larger towards the inner and outer margins, a feature which he subsequently contrasted with the condition in another new genus and species from the Pentlands, Scotoharpes domina, which was recovered from undoubted Silurian rocks in the inlier (Clarkson and Howells 1981). Metaharpes was simply wated in the milobite treatise (Moore 1959) but was provisionally considered a junior synonym of Hibbertia Jones and Woodward 1898, by Přibyl and Vanek (1986, pp. 23-24, table 1) who therefore tentatively extended the range of that genus into the Silurian on the basis of the presumed Llandovery age of the Loganlee clasts. The reassignment of Lamont's species to Hibbertia may indeed be correct and the length to width ratio is identical to that of the type species of that genus Hibbertia flanaganni (Portlock) (see Owen and Clarkson 1992, p. 11). The single available specimen from the Logan Burn, is not adequate to confirm this unequivocally. The revised Ordovician age for the Loganlee limestone clasts is compatible with the occurrence of Hibbertia elsewhere. It may be significant, in terms of the provenance of the limestone clasts, that the Loganlee

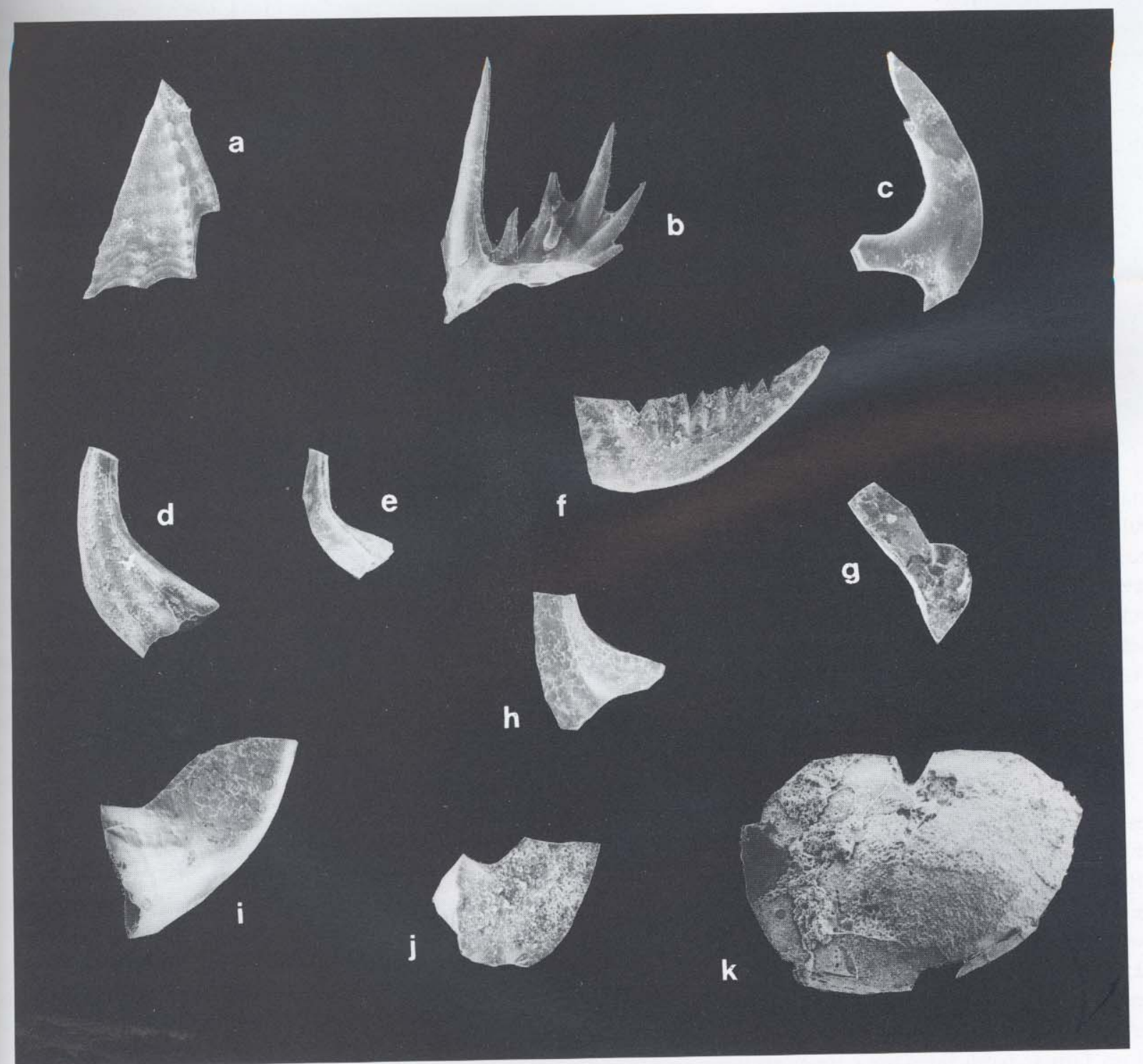

2. Conodonts and an ostracode from limestone clasts, Greywacke Conglomerate, Logan Burn, Pentland Hills. All specimens are housed in the Hunterian Museum and are prefixed by numbers GLAHM 111227 to GLAHM 111237. Sample numbers are those of the Micropalaeontological Collections of the Department of Geological Sciences, University of Durham. Full systematic descriptions of these taxa can be found in Armstrong (1997). (a) Pygodus anserinus (Lamont and Lindström 1957), specimen GLAHM 111227, sample D624, oral view of Pa element, $\times 70$. (b) Periodon aculeatus (Hadding 1913), specimen GLAHM 111228, sample D713, Pb element, $\times 50$. (c) Spinodus spinatus (Rhodes 1955), specimen GLAHM 111229, sample D709, $\times 70$. Fragment of an S element. (d) Panderodus sp. indet., specimen GLAHM 111230, sample D624, ×70. (e) Panderodus sp. indet., specimen GLAHM 111231, sample D624, qg element, $\times 70$. (f) Belodina confluens (Sweet 1979), specimen GLAHM 111232, sample D624, rastrate element, $\times 70$. (g) Strachanognathus parvus (Rhodes 1955), specimen GLAHM 111233, sample D624, fragment of a q element, $\times 70$. Fragment of a q element, the cusp is broken and only the lower edge denticle remains. (h) Dapsilodus mutatus (Branson and Mehl 1933), specimen GLAHM 111234, sample D624, ×70. (i) Walliserodus costatus (Dzik 1976), specimen GLAHM 111235, sample D624, $\times 70$. (j) ?Protopanderodus $\mathrm{sp}$. indet., specimen GLAHM 111236, sample D624, ×70. (k) Internal mould of an ostracode, a possible Leperditella species, specimen GLAHM 111237 , sample D624, $\times 50$. 
harpid is certainly not conspecific with the harpid specimen, Dubhglasina parvula (M'Coy 1851), known from limestone clasts of similar early Caradoc age in the upper Ordovician Wrae Limestone in the Northern Belt of the Southern Uplands (see Owen et al. 1996, p. 140, fig. 3C). The Wrae Limestone form has a broader anterior part of the fringe; that from Loganlee being narrower (sag.) frontally but broadening anterolaterally. It also differs in the width of the fringe from the harpid lower lamella illustrated by Tripp (1979) as ?Paraharpes from the uppermost Stinchar Limestone at Brochloch in the Girvan district. The Girvan form maintains its width except towards the ends of the genal prolongations.

Professor D. A. T. Harper of Copenhagen University informs us (pers. comm. 1999) that preliminary analysis of the brachiopods from limestone clasts in the BGS collections indicates an upper Ordovician assemblage, dominated by a species of Sowerbyella but also including Paralenorthis, Nicolella, Oxoplecia, Christiania, Strophomena, Leptaena and possibly Rafinesquina. He also notes that the dominance of Sowerbyella suggests a deep shelf community, deeper than that represented in the Wrae Limestone fauna (Owen et al. 1996). A more detailed analysis will form part of a future work on the systematic palaeontology of the shelly fauna.

Identifiable fragmentary conodonts have been extracted from three samples (D624, D709, D713 sample numbers of the Micropalaeontology Collection, Department of Geological Sciences, University of Durham) using standard methods (Stone 1987). All the specimens of the faunule are illustrated in Fig.2. Preservation is poor; specimens have a CAI of 7 indicating heating to $480-610^{\circ} \mathrm{C}$ (Rejebian et al. 1987) and exhibit surface recrystallisation. One clast (sample D624) contains a single specimen of the $\mathrm{Pa}$ element of eponymous biozonal species Pygodus anserinus Lindström 1957 (Fig. 2a), characterised by four rows of nodes on the oral surface (see also Armstrong 1997).

\section{Regional correlations}

Bergström (1971) described conodonts from the Middle and Upper Ordovician of the Girvan area, and subsequently (Bergström 1990) presented a detailed biostratigraphical analysis of these faunas. The base of the $P$. anserinus Biozone lies within the upper part of the Stinchar Limestone and its top falls at some level within the Benan Conglomerate.

Armstrong (1997) re-described P. anserinus Biozone conodont faunas from limestone clasts (the Wrae Limestone) in the Ashgill Tweeddale Member of the Shinnel Formation in the Northern Belt of the Southern Uplands. Conodonts of $P$. anserinus Biozone age are also abundant in upper Llanvirn (Llandeilian) to lowest Caradoc red cherts and mudstones in the northern Southern Uplands (Armstrong et al. 1998). These lie above volcanic rocks in the most northerly thrust slice (e.g. localities 108-110, Bergström and Orchard 1985) and within the Kirkcolm Formation between the Carcow and Leadhills faults (Armstrong et al. 1990, 1998; Armstrong unpublished collections; Owen et al. 1999). These conodont faunas are associated with gracilis Biozone graptolites indicative of an Aurelucian, early Caradoc age (sensu Fortey et al. 1995)

\section{Regional Implications}

There are no Ordovician rocks exposed within the Pentland Hills inlier, and thus our new age data suggest that along with the other clasts, the limestones in the Greywacke Conglomerate in the Logan Burn are exotic to the Pentlands Sub-basin. The source area had a cover succession that included mid-Ordovician shallow marine carbonate and flysch.

Limestone clasts are also known from conglomerates in the Crawton Group at Inverbervie, in the Strathmore Basin (Haughton 1988). A single limestone clast from this locality has yielded an Ordovician brachiopod provisionally assigned to the Lower Ordovician genus Archaeorthis by Ingham et al. (1986, fig. 2b, c). This specimen is extremely poorly preserved and its identification is probably best considered as no more than an indeterminate orthidine (pers. comm. D. A. T. Harper). Haughton (1988; see also Haughton and Halliday 1991) suggested that this and other limestone clasts together with associated greywacke, igneous and hornfels clasts were derived from the south. A cryptic terrane lying to the south and east of the Midland Valley may therefore have provided detritus to the Lanark and Strathmore basins during the late Silurian to early Devonian.

\section{Conclusions}

Limestone clasts from the southerly-derived Greywacke Conglomerate Formation in the Pentland Hills Sub-basin yield a conodont faunule that belongs in the uppermost Llanvirn to lower Caradoc Pygodus anserinus Biozone. This date constrains the age of the cover succession of a cryptic terrane that lay to the south and east of the Midland Valley during the late Silurian to early Devonian. Rare occurrences of Ordovician limestone clasts in the Crawton Group of the Strathmore basin, may indicate detritus from this cryptic terrane was distributed over a much wider area.

\section{Acknowledgements}

We thank Trevor Morse who processed the samples, Dr Martin Lee and Gerry Dresser who printed the photographs and Karen Atkinson who drew the diagrams. Dr Mark Williams (British Geological Survey) identified the ostracode specimen. This work was funded by a N.E.R.C. Small Grant (GR9/02834) held by H.A.A. and A.W.O.

\section{References}

ARMSTRONG, H. A. 1997. Conodonts from the Shinnel Formation, Tweeddale Member (middle Ordovician), Southern Uplands, Scotland. Palaeontology 40, 763-799.

, RUSHTON, A. W. A., OWEN, A. W. and FLOYD, J. D. 1998. Biostratigraphy of the Currarie Formation on the northwestern edge of the Southern Uplands - implications for the cessation of basic volcanism. Scottish Journal of Geology 34, 119-25.

, CLARKSON, E. N. K. and OWEN, A. W. 1990. A new 
Lower Ordovician conodont faunule from the Northern Belt of the Southern Uplands of Scotland. Scottish Journal of Geology 26, 47-52.

BERGSTRÖM, S. M. 1971. Conodont biostratigraphy of the Middle and Upper Ordovician of Europe and eastern North America. Geological Society of America Memoir 127, 83-157. 1990. Biostratigraphic significance of Middle and Upper Ordovician conodonts in the Girvan Succession, south-west Scotland. Courier Forschungsinstitut Senckenberg 118, 1-43. and ORCHARD, M. J. 1985. Conodonts of the Cambrian and Ordovician Systems from the British Isles. In Higgins, A. C. and Austin, R. L. (eds.) A stratigraphical index of conodonts. Ellis Horwood, Chichester, 32-67.

BLUCK, B. J. 1978. Sedimentation in a late orogenic basin: the Old Red Sandstone of the Midland Valley of Scotland. In Bowes, D. R. and Leake, B. E. (eds.) Crustal Evolution in Northwestern Britain and adjacent Regions. Geological Journal, Special Issue 10, 249-279.

1983. Role of the Midland Valley of Scotland in the Caledonian Orogeny. Transactions of the Royal Society of Edinburgh: Earth Sciences 73, 119-136.

1984. Pre-Carboniferous history of the Midland Valley of Scotland. Transactions of the Royal Society of Edinburgh: Earth Sciences 75, 275-295.

BULL, E. E. and LOYDELL, D. K. 1995. Uppermost Telychian graptolites from the North Esk Inlier, Pentland Hills, near Edinburgh. Scottish Journal of Geology 31, 163-171.

CLARKSON, E. N. K. and HOWELLS, Y. 1981. Upper Llandovery trilobites from the Pentland Hills, Scotland. Palaeontology 24, 507-536.

FORTEY, R. A., HARPER, D. A. T., INGHAM, J. K., OWEN, A. W. and RUSHTON, A. W. A. 1995. A revision of the Ordovician Series and Stages in the historical type area. Geological Magazine 132, 15-30.

HAUGHTON, P. D. W. 1988. A cryptic Caledonian flysch terrane in Scotland. Journal of the Geological Society, London 145, 685-703.

and HALLIDAY, A. N. 1991. Significance of late Caledonian igneous complex revealed in the Lower Old Red Sandstone conglomerates, central Scotland. Geological Society of America Bulletin 103, 1476-92.

HENDERSON, J. 1874. Notice of some Fossils from the Conglomerate at Habbie's Howe, Logan Burn, near Edinburgh. Transactions of the Edinburgh Geological Society 2, 389-390.

- 1880. On some recently discovered Fossiliferous Beds in the Silurian Rocks of the Pentland Hills. Transactions of the Edinburgh Geological Society 3, 353-356.

INGHAM, J. K., CURRY, G. B. and WILLIAMS, A. 1986. Early Ordovician Dounans Limestone fauna, Highland Border Complex, Scotland. Transactions of the Royal Society of Edinburgh: Earth Sciences 76, 481-513.

JONES, T. R. and WOODWARD, H. 1898. A monograph of the British Palaeozoic Phyllopoda (Phyllocarida Packard). Monograph of the Palaeontographical Society, London.

LAMONT, A. 1948. Scottish Dragons. Quarry Managers' Journal 31, 531-535.

M'COY, F. 1851. On some Cambro-Ordovician fossils. Annals and Magazine of Natural History 8, 387-409.

McGIVEN, A. 1967. Sedimentation and provenance of some postValentian conglomerates, Midland Valley, Scotland. University of Glasgow Ph.D. Thesis (unpublished).

MITCHELL, G. H. and MYKURA, W. 1962. The Geology of the Neighbourhood of Edinburgh. (Explanation of one-inch sheet 32) Memoir of the Geological Survey, Scotland. Third Edition. H. M. S. O.

MOORE, R. C. (ed.) 1959. Treatise on Invertebrate Paleontology. Part $O$, Arthropoda I. Geological Society of America and University of Kansas Press, Boulder, Colorado and Lawrence, Kansas.

MYKURA, W. 1960. The Lower Old Red Sandstone igneous rocks of the Pentland Hills. Bulletin of the Geological Survey of Great Britain 16, 131-155.

- 1986. Pentland Hills. In McAdam, A. D. and Clarkson, E. N. K. (eds.), Lothian Geology, An excursion guide. 161-174. Edinburgh Geological Society,

NICHOLSON, H. A. and ETHERIDGE, R. Jr. 1877. Contributions to Micro-Palaeontology - I. On the Genus Tetradium Dana, and on a British Species of the same. Annals and Magazine of Natural History 20, 161-169.

- and - 1878. A monograph of the Silurian fossils of the Girvan district in Ayrshire, with special reference to those contained in the Gray collection. Volume 1, Fasciculus 1. W. Blackwood and Sons, Edinburgh and London.

- and - 1885. On the synonymy, structure and geological distribution of Solenopora compacta Billings sp. Geological Magazine (NS Dec 3) 2, 529-535.

OWEN, A. W. and CLARKSON, E. N. K. 1992. Trilobites from Kilbucho and Wallace's Cast and the location of the Northern Belt of the Southern Uplands during the late Ordovician. Scottish Journal of Geology 28, 3-17.

- HARPER, D. A. T. and CLARKSON, E. N. K. 1996. The trilobites and brachiopods of the Wrae Limestone, an Ordovician limestone conglomerate in the Southern Uplands. Scottish Journal of Geology 32, 133-149.

- ARMSTRONG, H. A. and FLOYD, J. D. 1999. Rare Earth Element geochemistry of upper Ordovician cherts from the Southern Uplands of Scotland. Journal of the Geological Society, London 156, 191-204.

PEACH, B. N. and HORNE, J. 1899. The Silurian rocks of Britain, 1: Scotland. Memoir of the Geological Survey of the United Kingdom.

, CLOUGH, C. T., HINXMAN, L. W., GRANT WILSON, J. S., CRAMPTON, C. D., MAUFE, H. B. and BAILEY, E. B. 1910. The Geology of the neighbourhood of Edinburgh. (Explanation of Sheet 32 with part of sheet 31). Memoir of the Geological Survey of Scotland 2nd edition.

PHILLIPS, E. R., SMITH, R. A. and CARROLL, S. 1998. Strikeslip, terrane accretion and pre-Carboniferous evolution of the Midland Valley of Scotland. Transactions of the Royal Society of Edinburgh: Earth Sciences 89, 209-224.

PŘIBYL, A. and VANEK, J. 1986. A study of the morphology and phylogeny of the Family Harpetidae Hawle and Corda, 1847 (Trilobita). Sbornik Narodniho Muzea v Praze 42B, 1-72.

REJEBIAN, V. A., HARRIS, A. G. and HUEBNER, J. S. 1987. Conodont color and texture alteration: An index to regional metamorphism, contact metamorphism and hydrothermal alteration. Geological Society of America Bulletin 99, 471-479.

ROBERTSON, G. 1989. A palaeoenvironmental interpretation of the Silurian rocks of the Pentland Hills, near Edinburgh. Transactions of the Royal Society of Edinburgh: Earth Sciences 80, 127-141.

STONE, J. 1987. Review of the investigative techniques used in the study of conodonts. In Austin, R. L. (ed.), Conodonts: Investigative techniques and applications. Ellis Horwood, Chicester, 17-35.

SYBA, E. 1989. The sedimentation and provenance of the Old Red Sandstone Greywacke Conglomerate, southern Midland Valley, Scotland. University of Glasgow, $\mathrm{PhD}$ thesis, (unpublished).

THIRLWALL, M. F. 1988. Geochronology of British Late Caledonian magmatism in northern Britain. Journal of the Geological Society, London 145, 951-67.

TRIPP, R. P. 1979. Trilobites from the Ordovician Auchensoul and Stinchar Limestones of the Girvan District, Strathclyde. Palaeontology 22, 339-361.

TUCKER, R. D., BRADLEY, D. C., VERSTRAETEN, C. A., HARRIS, A. G., EBERT, J. R. and McCUTCHEON, S. R. 1998. New U-Pb Zircon ages and the duration and division of Devonian time. Earth and Planetary Science Letters 158, 175-186. 